\title{
STRONG CONVERGENCE OF ISHIKAWA ITERATIVE METHOD FOR NONEXPANSIVE MAPPINGS IN HILBERT SPACES
}

\author{
MeiJuan Shang, XiaOlong Qin and Yongfu Su
}

\begin{abstract}
In this paper, we introduce a modified Ishikawa iterative process for approximating a fixed point of nonexpansive mappings in Hilbert spaces. we establish the strong convergence theorem of the general iteration scheme under some mild conditions. Our results extend and improve the results announced by many others.
\end{abstract}

Mathematics subject classification (2000): 47H09, 47H10.

Key words and phrases: Nonexpansive mapping, Hilbert space, variational inequality.

\section{REFERENCES}

[1] F. DEUTSCH, I. YAMADA, Minimizing certain convex functions over the intersection of the fixed point set of nonexpansive mappings, Numer. Funct. Anal. Optim. 19 (1998) 33-56.

[2] A. Genel, J. Lindenstrauss, An example concerning fixed points, Israel J. Math. 22 (1975) 81-86.

[3] S. IshiKaWA, Fixed points by a new iteration method, Proc. Am. Math. Soc. 44 (1974) 147-150.

[4] T. H. KIM, H. K. XU, Strong convergence of modified Mann iterations, Nonlinear Anal. 61 (2005) 51-60.

[5] G. MARINO AND H. K. XU, A general iterative method for nonexpansive mappings in Hilbert spaces, J. Math. Anal. Appl. 318 (2006) 43-52.

[6] W. R. MAnN, Mean value methods in iteration, Proc. Amer. Math. Soc. 4 (1953) 506-510.

[7] A. MoudAFI, Viscosity approximation methods for fixed points problems, J. Math. Anal Appl. 241 (2000) 46-55.

[8] S. REICH, Weak convergence theorems for nonexpansive mappings in Banach spaces, J. Math. Anal. Appl. 67 (1979) 274-276.

[9] T. SuZUKI, Strong convergence of Krasnoselskii and Mann's type sequences for one-parameter nonexpansive semigroups without Bochner integrals, J. Math. Anal. Appl. 305 (2005) 227-239.

[10] Y. F. SU, X. L. QIN, Strong convergence theorems for nonexpansive mapping, J. Syst Sci Complexity 20 (2007) 85-94

[11] K. K. TAN, H. K. XU, Approximating fixed points of nonexpansive mappings by the Ishikawa iteration process, J. Math. Anal. Appl. 178 (2) (1993) 301-308.

[12] H. K. XU, Strong convergence of an iterative method for nonexpansive and accretive operators, J. Math. Anal. Appl. 314 (2006) 631-643.

[13] H. K. XU, Iterative algorithms for nonlinear operators, J. London Math. Soc. 66 (2002) 240-256.

[14] H. K. XU, An iterative approach to quadratic optimization, J. Optim. Theory Appl. 116 (2003) 659-678.

[15] I. YAMADA, The hybrid steepest descent method for the variational inequality problem of the intersection of fixed point sets of nonexpansive mappings, in: D. Butnariu, Y. Censor, S. Reich (Eds.), Inherently Parallel Algorithm for Feasibility and Optimization, Elsevier, 2001, pp. 473-504.

[16] Y. YAO, R. D. ChEN, Y. C. Y, Strong convergence and certain control conditions for modified Mann iteration, Nonlinear Anal. (2007), doi:10.1016/j.na.2007.01.009. 